\title{
Türkiye'nin İhracat Talebi Fonksiyonunun Farklı Ülke Gruplarına Göre Eşbütünleşme Analizi
}

\author{
Naib ALAKBAROV ${ }^{1} \quad$ Murat GÜNDÜZ ${ }^{2}$ \\ Mehmet Hilmi ÖZKAYA ${ }^{3}$ \\ $\ddot{\boldsymbol{O}} z$
}

\begin{abstract}
Türkiye 24 Ocak 1980 kararlart ile ihracata dayalı sanayileşme stratejisi uygulamaya koyarak dünya ekonomisiyle bütünleşmeyi hedeflemiş ve böylelikle uluslararası rekabeti ön plana çıkaran büyüme modelini benimsemiştir. Türkiye 1980'li yıllardan itibaren aynı zamanda dış ticaret pazarlarını da çeşitlendirmeyi amaçlamıştır. Bu bağlamda özellikle 2000 'li yıllardan itibaren yapılan Pazar çeşitlendirmesi tartışmalarl ile Türkiye'nin Orta Doğu ve Asya pazarlarına yöneldiği ve bu bölgelerin Türkiye dlş ticareti açısından önemli potansiyel taşıdı̆̆ ifade edilmektedir. Bu çalışma, Türkiye'nin 2001-2013 dönemi çeyreklik verileri kullanarak yapılan ihracat talebinin ekonometrik analizini içermektedir. Bu çalışmada Türkiye 'nin ihracat potansiyelinin farkl bölgelere yönelik ihracat talebinin fiyat ve gelir esnekliği analizi yapılmaktadır. Yapılan analiz sonucu Türkiye'nin ihracat pazarı olarak gelişmiş ülkeler grubunun öne çıktığl görülmektedir.
\end{abstract}

Anahtar Kelimeler: Ihracat Talebi Fonksiyonu, Dış Ticaret Pazarlarl Sorunu, Eşbütünleşme Analizi.

Jel Sinıflandirma Kodları: F13, F14, O24, C50.

\section{The Cointegration Analysis of Turkey's Export Demand Function by Group of Different Countries}

\begin{abstract}
Turkey adopted the export-oriented industrialization strategy with the decisions of January 24, 1980 and aimed to integrate with the world economy, After this date Turkey adopted the growth model that gives especially priority to international competition. Turkey also aims to diversify foreign trade markets in this period as well. In this context, it has been expressed that Turkey has moved to the Middle East and Asian markets since the year 2000 and these regions have important potential for foreign trade in Turkey. This study includes a cointegration analysis of export demand made using quarterly data covering the years from 2001 to 2013 of Turkey. In this study, the export potential of Turkey is analyzed for different regions. As a result of the analysis, it is seen that the most important market of Turkey as export market is developed countries.
\end{abstract}

Keywords: Export Demand Function, Foreign Trade Markets Problem, Cointegration Analysis.

\footnotetext{
${ }^{1}$ Yard. Doç. Dr., Uşak Üniversitesi, İktisadi ve İdari Bilimler Fakültesi, İktisat Bölümü, naib.alakbarov@usak.edu.tr

${ }^{2}$ Yard. Doç. Dr., Uşak Üniversitesi, İktisadi ve İdari Bilimler Fakültesi, Ekonometri Bölümü, murat.gunduz@usak.edu.tr

${ }^{3}$ Doç. Dr., Uşak Üniversitesi, İktisadi ve İdari Bilimler Fakültesi, İktisat Bölümü, mehmethilmi.ozkaya@usak.edu.tr
} 


\section{N.ALAKBAROV -M.GÜNDÜZ -M.H.ÖZKAYA \\ Jel Classification Codes: F13, F14, O24, C50.}

\section{GíRİş}

İhracat talebi fonksiyonun analiz edilmesi tüm ülkeler açısından önem taşımaktadır. Gelişmekte olan ülkeler dikkate alındığında bu önem daha da artmaktadır. Çünkü ülkelerin göreli fiyat ve gelir esneklikleri birçok ülkede izlenen ihracata dayalı büyüme ve sanayileşme politikalarının kapsamını veya etkilerini ortaya koymaktadır. Bu değerlerin yüksek olması ülke bakımından ihracata dayalı büyüme politikasının etki alanının geniş olması anlamını taşır. Bu bağlamda Türkiye'nin ihracat talebi fonksiyonunun analiz edilmesi ve doğru tahmin edilmesi, uygulanan ve uygulanacak dış ticaret politikalarının etkilerinin değerlendirilmesi ve hedeflenen doğrultuda oluşturulması ve beklenen sonuçların önceden öngörülmesine yardımcı olacaktır.

2000'li yıllardan itibaren Türkiye'nin Orta Doğu ve Asya pazarlarına yöneldiği ve bu bölgelerin Türkiye dış ticareti açısından önemli potansiyel taşıdığı tartışma konusu olmaktadır. Dolayısıyla bu çalışmada 2001-2013 dönemi Türkiye'nin ihracat talebinin gelir ve fiyat esneklikleri hesaplanmakta ve söz konusu tartışmalara katkı sağlayacak bulgulara ulaşılmaktadır. Böylelikle Türkiye'nin cari açık sorununun giderilmesi açısından ihracat pazarlarının karşılaştırılması ve uzun dönemde hangi pazarlara daha çok önem vermesi gerektiğinin tartışılması amaçlanmaktadır.

Araştırmada ilk olarak bu konuya ilişkin literatür incelemesi sunulmaktadır. İkinci olarak modelin belirlenmesi ve veriler ele alınmaktadır. Son olarak araştırmanın bulguları ve bu bulgulara bağlı ortaya çıkan öneriler yer almaktadır.

\section{LITERATÜR İNCELEMESİ}

İhracata yönelik büyüme modelini benimseyen azgelişmiş ve/veya gelişmekte olan ülkelerin ihracat fonksiyonlarının tahmin edilmesi, ihracat talebinin gelir ve fiyat esnekliklerinin değerleri bu ülkelerin büyüme potansiyellerini yansıtması nedeniyle önem arz etmektedir (Rao ve Singh, 2007). Buna ilave olarak söz konusu değerlerin özellikle gelişme yolundaki ülkelerin dış ticaret politikası uygulamaları 
ve ödemeler dengesi sorununun çözümünde yol gösterici olması sebebiyle akademik yazında ilgi çekmektedir (Fullerton vd., 1999).

Konuyla ilgili olarak Senhadji ve Montenegro (1999) tarafından 1960-1993 yıllık verileri ve EKK yöntemi kullanılarak gelişmiş ve gelişmekte olan ülke gruplarını ele alan çalışmalarında Türkiye için gelir esnekliğinin kısa dönemde 0,06 ve uzun dönemde 0,51 olduğu belirtilmektedir. Söz konusu çalışma Türkiye'nin fiyat esnekliğinin kısa dönem için $-0,58$, uzun dönem için de 5,38 gibi bir değer aldığını göstermektedir.

Erdoğan Coşar (2002), Togan ve Berument (2007) ve Çulha ve Kalafatcılar (2014) tarafından yapılan çalışmalarda Türkiye'nin ihracat talebinin gelir esnekliği oldukça yüksek hesaplanmıştır. Erdoğan Coşar (2002) 1989-2000 döneminde üç aylık veriler yardımıyla panel-eşbütünleşme analiz yöntemini kullanarak yaptığı çalışmasında Türkiye'nin gelir esneklik katsayısını kısa dönemde 3,84 ve uzun dönemde de 4,5 olarak hesaplamaktadır. Bu araştırmaya göre fiyat esnekliği katsayıları kısa dönemde $-0,58$ ve uzun dönemde 0,4 'tür. İlgili çalışma uzun dönem kur esnekliğinin ihracatta giderek daha fazla ithal girdi kullanılması nedeniyle beklenenin aksine pozitif işaretli bulunduğunu ileri sürmektedir. Doğanlar, Bal ve Özmen (2004) tarafından 1981-1999 arası üç aylık verileri kullanarak eşbütünleşme analizi yardımı ile yapılan çalışma gelir esnekliğini uzun dönem için 3,08 ve fiyat esnekliğini de -1,07 olarak bulmuştur. Togan ve Berument (2007) tarafından 19702005 y1llık verileri kullanılarak eşbütünleşme analizi yöntemi ile yapılmış çalışmada Türkiye için uzun dönem gelir esnekliği 3,41 ve fiyat esnekliği ise 0,34 bulunmuştur. Çulha ve Kalafatcılar (2014) tarafindan yapılan araştırmada 2003-2013 dönemi Türkiye'nin ihracat talep fonksiyonu VAR analizi ile incelenmiştir. Çalışmada ihracatın gelir esnekliği gelişmiş ülkelerde, özellikle de Euro Bölgesi’nde, daha yüksek bulunmuş ve reel ihracatın eşanlı gelir esnekliği Euro Bölgesi’nde 5,3, diğer gelişmiş ülkelerde ise 3,2 olarak hesaplanmıştır. Orta Doğu ve Afrika ile diğer gelişmekte olan ülkelerde ise söz konusu esneklik değeri sırasıyla 0 ve 0,97 olarak bulunmuştur. Orta Doğu ve Afrika bölgesine yapılan ihracatın eşanlı reel kur 


\section{N.ALAKBAROV -M.GÜNDÜZ -M.H.ÖZKAYA}

esnekliği -0,39 olarak hesaplanmış ve bu değerin takip eden dönemlerde $-0,7$ ile $-0,9$ arasında seyrettiği tahmin edilmiştir.

Şimşek ve Kadılar (2005) çalışmalarında Türkiye'nin 1970- 2002 dönemini kapsayan y1llık verileri kullanarak yapılan ihracat talep fonksiyonunu Pesaran vd. (2001)'nin sınır testi yöntemini kullanarak analiz etmişlerdir. Araştırma sonuçlarına göre, ihracatla, gelir ve nispi fiyatların eşbütünleşik oldukları görülmüştür. İhracat talebinin, gelir ve nispi fiyatlara göre tahmin edilen uzun dönem esneklikleri sırayla; 0.21 ve -1.684 olarak bulunmuştur. İthalat ve ihracat fiyat esnekliklerinin toplamı birden büyük olduğu belirlenmiştir.

Aydın, Saygılı ve Sayg11ı (2007) tarafindan 1987-2006 yıllık verileri kullanılarak Kalman filtresi yöntemi ile yapılan analizde gelir esnekliği kısa dönemde 1,32 bulunurken, uzun dönemde ise 1,45 bulunmuştur. Fakat ilgili çalışma uzun dönemli fiyat esnekliğini $-0,09$ ve kısa dönem fiyat esnekliğini ise $-0,35$ bulmuş ve ihracatın kura duyarlılı̆̆ının zaman içerisinde azalmasını ihracatta daha fazla ithal girdi kullanımına bağlamıştır.

Aktaş ve Yılmaz (2008) çalışmalarında 1996-2005 dönemi için Gümrük Birliği sonrası Türkiye'nin ihracat fonksiyonunu tahmin etmişlerdir. Çalışmada, ihracatı etkileyen en önemli değişkenin ithalat olduğu tespit edilmiştir. Araştırmada dolar kuru sabit kalmak koşuluyla ithalat değerlerindeki bir birimlik artışın, ihracat değerini 0,84 birim artırdığı belirlenmiştir.

Kumar (2011) Asya'nın gelişmekte olan ülkeleri Çin, Hindistan, Filipinler, Endonezya, Singapur ve Malezya'ya yönelik yaptığı çalışmada uzun dönemli gelir esnekliğinin Singapur ve Çin için yaklaşık 1,3; Malezya ve Hindistan için yaklaşı 1,2 ve Filipinler ve Endonezya için yaklaşık 1 olarak bulmuştur. Ayrıca ilgili çalışma söz konusu ülkelere yönelik uzun dönemli fiyat esnekliğinin ise -1 ile -1,4 arasında değiştiğini ortaya koymakta, Hindistan ve Singapur için yaklaşık -1,4; Filipinler ve Çin için yaklaşık -1,3; Endonezya için yaklaşık -1,1 ve Malezya için yaklaşık -1 olduğunu ifade etmektedir (Kumar, 2011). 
Ketenci (2014) yaptığı çalışmada BRIICS (Brazilya, Rusya, Hindistan, Endonezya, Çin ve Güney Afrika) ve Türkiye için finansal krizlerin ihracat ve ithalat esneklikleri üzerinde yaptığı etkiyi araştırmış ve döviz kurunda ve emtia fiyatlarında meydana gelen değişmelerin ülkelerin ihracat ve ithalat esnekliklerini değiştirmediği sonucuna ulaşmıştır.

Bozok, Şen Doğan ve Yüncüler (2015) tarafından yapılan çalışmada Türkiye'nin farklı ülke gruplarına yönelik ihracat talebinin gelir ve fiyat esnekliği hesaplanmış ve gelir esnekliğinin tüm ülke gruplarında fiyat esnekliğinden yüksek olduğu sonucuna ulaşılmıştır. Gelir esnekliğinin 1,82 ve 3,35 aralığında değiştiğini, fiyat esnekliğinin de $-1,56$ ile $-0,27$ aralığında değiştiğini ortaya koyan çalışmada, gelir esnekliğinin özellikle AB 27 ülkeleri için diğer ülke gruplarıyla kıyaslandığında daha yüksek olduğu ifade edilmektedir.

\section{MODEL VE VERİ SETİ}

$\mathrm{Bu}$ çalışma, Türkiye'nin 2001-2013 dönemini kapsayan çeyreklik veriler kullanarak yapılan ihracat talebinin eşbütünleşme analizini içermektedir. Çalışmada kullanılan veriler Uluslararas1 Para Fonu'nun International Financial Statistics (IFS) verilerinden elde edilmiştir. Söz konusu veriler ilgili ülke gruplarına yönelik ihracat fiyat ve miktar endeksleri ve GSYH değerlerini içermektedir. Analizde kullanılan ülke grupları IMF tarafından yapılan sınıflandırmayı esas almaktadır ${ }^{4}$.

İhracat talep fonksiyonu tahmin edilirken aşağıdaki fonksiyon dikkate alınmıştır (Khan, 1974):

$$
X_{t}=f\left(Y^{*}, P_{x} / P_{w}, R\right)
$$

$\mathrm{X}_{\mathrm{t}}$ - İhracat miktar endeksi; $\mathrm{Y}^{*}$ - İhraç edilen ülke grubu reel GSYH's1; $\mathrm{P}_{\mathrm{x}}$ - ihracat fiyat endeksi (ABD Doları cinsinden); $\mathrm{P}_{\mathrm{w}}$ - İhraç edilen ülke grubu GSYH deflatörü

\footnotetext{
${ }^{4}$ İlgili ülke gruplarına yönelik detaylı bilgi için bakınız: IMF, World Economic Outlook Database-WEO Groups and Aggregates Information, https://www.imf.org/external/pubs/ft/weo/2017/01/weodata/groups.htm (05.08.2017).
} 


\section{N.ALAKBAROV -M.GÜNDÜZ -M.H.ÖZKAYA}

ve ithalat fiyat endeksi; R- Euro/Dolar çapraz kuru. Bu bağlamda aşağıdaki logaritmik model tahmin edilmektedir:

$$
\ln X_{t}^{d}=b_{0}+b_{2} \operatorname{lnGDPW} W_{t}-b_{1} \ln \left(P_{x} / P_{w}\right)_{t}+R+u_{t}
$$

Eşitlik (1)'deki modelde ifade edilen $\mathrm{P}_{\mathrm{x}} / \mathrm{P}_{\mathrm{w}}$ değişkeni rekabet değişkenini temsil etmektedir. $\mathrm{Bu}$ bağlamda belirtilen değişkenin tanımlanmasında literatürdeki çalışmalardan şu yönüyle farklılık arz etmektedir: Rekabet endeksi hesaplanırken, hem Türkiye'nin ihracat firmalarının ihraç edilen ülke grubu yerel firmaları ile, hem de o ülkeye ihracat yapan diğer ülke firmaları ile rekabet ettikleri esası dikkate alınmaktadır. Bu yüzden rekabet endeksi değişkeninde $\mathrm{P}_{\mathrm{w}}$ değişkeni olarak ilgili ülke grubu GSYH deflatörü dikkate alındığında, modelde Türkiye'de yerleşik firmaların o ülke grubu firmaları ile rekabet ettikleri varsayımı yapılmaktadır. Eğer $\mathrm{P}_{\mathrm{w}}$ olarak ilgili ülke grubu ithalat fiyatları dikkate alınırsa, Türkiye'nin ihracat firmalarının ilgili ülke grubuna ihracat yapan diğer ülke firmaları ile rekabet ettikleri varsayılmaktadır. Bundan dolayı çalışmada rekabet değişkeni oluşturulurken her iki fiyat endeksi dikkate alınmıştır.

İhracat talep modeli oluşturulurken tüm dünya ülkelerinin yanında farklı ülke grupları da dikkate alınmaktadır. İhracat talep denklemi Dünya geneli, Orta Doğu Afrika ülke grubu, Gelişmekte Olan Ülkeler grubu, Gelişmekte Olan Asya Ülkeleri grubu, APEC Ülke Grubu ve Gelişmiş Ülkeler grupları için ayrı ayrı hesaplanmıştır. Analizin farklı ülke gruplarına yönelik yapılması, Türkiye'nin ihracat pazarlarının değerlendirilmesinde ülke gruplarının karşılaştırılmasına olanak sağlayacağı düşünülmektedir.

Araştırmada aynı zamanda çapraz kur değişkeni de kullanılmaktadır. Türkiye, ihracatında Euro para birimini ağırlıklı olarak kullanırken (Saatçioğlu ve Karaca, 2010), ithalatında ise ABD Doları para birimini ağırlıklı olarak kullanmaktadır ve bu yüzden Türkiye'nin ihracatı açısından Euro para birimi, ithalatı açısından ise ABD Doları para birimindeki gelişmeler önemlidir. Dolayısıyla Euro/Dolar çapraz kurdaki gelişmeler Türkiye'nin dış ticaretini etkilemektedir. Euro para biriminin Dolara karşı değer kaybetmesi (çapraz kurun düşmesi) Türkiye'nin ihracatı 
açısından olumsuz etki yaratmaktadır. Çapraz kurun yükselmesi (Euro'nun değerinin yükselmesi) ise Türkiye ihracatını olumlu etkilemektedir. Bu çerçevede modelde çapraz kur değişkeninin işaretinin pozitif çıkması beklenmektedir.

Zaman serilerine dayanan modellerde verilerin "durağan" olması önemlidir. Durağan süreç, ortalaması ve varyansı zaman içerisinde değişmeyen ve iki dönem arasındaki kovaryansın ise bakılan döneme değil de dönemlerin arasındaki uzaklığa bağl1 olduğu süreçtir. Granger ve Newbold (1974) durağan olmayan zaman serileriyle çalışılması halinde sahte regresyon problemiyle karşılaşılabileceğini ifade ederek durağan olmayan serilerin kullanılması güvenilir olmayan sonuçların elde edilmesine neden olabileceğini belirtmektedirler. $\mathrm{Bu}$ sebeple zaman serileriyle yapılan regresyon analizlerinde ilk olarak kullanılan değişkenlerin durağanlık testlerinin yapılması gerekmektedir. Bu çalışmada uygulamada serilerin durağanlık özelliklerinin test edilmesinde Dickey ve Fuller (1979) ve Genişletilmiş Dickey ve Fuller (ADF) (1981) testleri kullanılmıştır.

Dickey-Fuller testi (1979) zaman serisi değişkenlerinin otoregresif süreçle (AR) oluşturulup oluşturulamayacağını göstermektedir. Dickey-Fuller ayrıca hata payları arasında korelasyon olması durumunda, bağımlı değişkenin gecikmeli değerlerinin modele dahil edilmesiyle Genişletilmiş Dickey-Fuller (ADF) (1981) adını verdikleri testi geliştirmişlerdir. $\mathrm{Bu}$ test için önerilen modeller aşağıdaki denklemlerde gösterilmiştir:

$$
\begin{aligned}
& \Delta \mathrm{Y}_{\mathrm{t}}=\gamma \mathrm{Y}_{\mathrm{t}-1}+\sum_{I=2}^{m} \beta_{1} \Delta \mathrm{Y}_{\mathrm{t}-\mathrm{i}+1}+\varepsilon_{\mathrm{t}} \\
& \Delta \mathrm{Y}_{\mathrm{t}}=\alpha_{0}+\gamma \mathrm{Y}_{\mathrm{t}-1}+\sum_{I=2}^{m} \beta_{1} \Delta \mathrm{Y}_{\mathrm{t}-\mathrm{i}+1}+\varepsilon_{\mathrm{t}} \\
& \Delta \mathrm{Y}_{\mathrm{t}}=\alpha_{0}+\gamma \mathrm{Y}_{\mathrm{t}-1}+\beta_{\mathrm{t}} \sum_{I=2}^{m} \beta_{1} \Delta \mathrm{Y}_{\mathrm{t}-\mathrm{i}+1}+\varepsilon_{\mathrm{t}}
\end{aligned}
$$

Birinci denklem katsayı ve trend etkisinin olmadığı yapıyı (2a), ikinci denklem sadece sabit katsayının olduğu yapıyı (2b), üçüncü denklem ise hem sabit hem de trend etkisinin gözlemlendiği yapıyı (2c) göstermektedir (Enders,1995).

Serilerin birim kök içerip içermediğinin tespitine yönelik Phillips-Perron (PP) (1988) testi de kullanılmıştır. PP (1988) testi zaman serilerindeki yüksek 


\section{N.ALAKBAROV -M.GÜNDÜZ -M.H.ÖZKAYA}

korelasyonu kontrol etmek için kullanılmaktadır. PP (1998) testi ADF testinden farklı olarak hata terimleri arasında zayıf bağımlılığa izin veren parametrik olmayan bir durağanlık testidir. PP (1988) testinin denklemi sabitli ve trendli olarak aşağıdaki gibidir:

$$
\Delta \mathrm{Y}_{\mathrm{t}-1}=\alpha_{0}+\alpha_{2} \mathrm{Y}_{\mathrm{t}-1}+\alpha_{2} \text { trend }+\mu_{\mathrm{t}}
$$

Değişkenlerin durağanlık analizi yapılmış ve sonuçlar Tablo 1'de gösterilmiştir. Tablo 1'deki birim kök sınama sonuçları, ADF ve PP birim kök testlerine dayanarak hem sabitli hem de sabitli ve trendli modeller esas alınarak hesaplanmıştır.

Tablo-1 incelendiğinde, yapılan test sonuçlarına göre tüm değişkenler I(1) özelliği göstermektedirler, yani birinci farklara göre durağan seri özelliğine sahiptirler. Bu durum Engel -Granger (1987) iki aşamalı eşbütünleşme yönteminin kullanılmasına olanak sağlamaktadır. Bu sebeple araştırmada söz konusu yöntemden yararlanılmıştır.

Modelde kullanılan kukla değişkenler her bir modelden elde edilen hata terimleri serisinin grafiğgindeki değişimler dikkate alınarak belirlenmiştir. Tüm modellerde kullanılan kukla değişkenler tablolarda belirtilen tarihe kadar "0", ilgili tarih ve sonrası için 1 olarak modele dahil edilmiştir. Bu şekilde modelde iki dönem arasında bağımlı değişkenin yapısında meydan gelen değişmeler gösterilmektedir.

Tablo 1. Değişkenlerin ADF ve PP Birim Kök Testleri

\begin{tabular}{|c|c|c|c|c|}
\hline & & Değişkenler & ADF & PP \\
\hline \multirow{14}{*}{ 总 } & \multirow{14}{*}{$\begin{array}{l}: \overrightarrow{0} \\
\text { 芯 } \\
\tilde{n}\end{array}$} & LNADVGDP & -1.65 & -2.01 \\
\hline & & LNADVANCEREKABET- İthalat Fiyatları & -1.88 & -1.87 \\
\hline & & LNAPECGDP & -1.14 & -2.09 \\
\hline & & LNAPECREKABET - İthalat Fiyatları & -1.76 & -1.68 \\
\hline & & LNEMDEVASİAGDP & & \\
\hline & & LNEMDEVASİAREKABET-İthalat Fiyatları & -1.61 & -1.47 \\
\hline & & LNEMDEVGDP & -0.93 & -1.33 \\
\hline & & LNEMDEVREKABET- İthalat Fiyatlar1 & -1.51 & -1.41 \\
\hline & & LNMEASTAFRGDP & -0.23 & 0.65 \\
\hline & & LNMEASTAFRREKABET-İthalat Fiyatlar1 & -1.76 & -1.68 \\
\hline & & LNWORLDGDP & -0.98 & -1.61 \\
\hline & & LNWORLDREKABET- İthalat Fiyatlar1 & -2.03 & -2.00 \\
\hline & & Değișkenler & $\mathrm{ADF}$ & PP \\
\hline & & LNADVANCEREKABET - Deflatör & -1.04 & -1.10 \\
\hline
\end{tabular}


Dokuz Eylül Üniversitesi İktisadi ve İdari Bilimler Fakültesi Dergisi Cilt:32, Sayl:2, Yll:2017, ss. 369-395

\begin{tabular}{|c|c|c|c|}
\hline & LNAPECREKABET - Deflatör & -1.61 & -1.87 \\
\hline & LNEMDEVASİAREKABET- Deflatör & -1.77 & -1.78 \\
\hline & LNEMDEVREKABET- Deflatör & -2.06 & -2.06 \\
\hline & LNMEASTAFRREKABET- Deflatör & -2.52 & -2.48 \\
\hline & LNWORLDREKABET- Deflatör & -2.55 & -2.35 \\
\hline \multirow{18}{*}{ 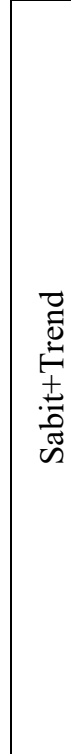 } & LNADVGDP & -3.00 & -2.96 \\
\hline & LNADVANCEREKABET- İthalat Fiyatları & -2.59 & -2.63 \\
\hline & LNAPECGDP & -1.93 & -3.21 \\
\hline & LNAPECREKABET - İthalat Fiyatları & -2.22 & -2.17 \\
\hline & LNEMDEVASİAGDP & -2.80 & -2.96 \\
\hline & LNEMDEVASİAREKABET- İthalat Fiyatları & -1.86 & -1.70 \\
\hline & LNEMDEVGDP & -2.92 & -3.68 \\
\hline & LNEMDEVREKABET-İthalat Fiyatları & -2.30 & -2.14 \\
\hline & LNMEASTAFRGDP & -1.45 & -1.38 \\
\hline & LNMEASTAFRREKABET-İthalat Fiyatları & -2.22 & -2.18 \\
\hline & LNWORLDGDP & -3.12 & -3.10 \\
\hline & LNWORLDREKABET-İthalat Fiyatları & -2.28 & -2.30 \\
\hline & LNADVANCEREKABET -Deflatör & -2.14 & -2.58 \\
\hline & LNAPECREKABET -Deflatör & -2.77 & -2.66 \\
\hline & LNEMDEVASİAREKABET-Deflatör & -2.35 & -2.38 \\
\hline & LNEMDEVREKABET-Deflatör & -3.05 & -3.02 \\
\hline & LNMEASTAFRREKABET-Deflatör & -2.64 & -2.66 \\
\hline & LNWORLDREKABET-Deflatör & -2.71 & -2.58 \\
\hline \multirow{25}{*}{ 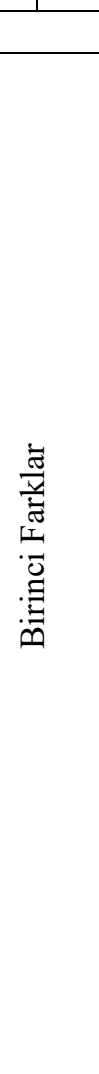 } & Değişkenler & $\mathrm{ADF}$ & $\mathrm{PP}$ \\
\hline & D(LNADVGDP) & $-8.30 *$ & $-11.40^{*}$ \\
\hline & D(LNADVANCEREKABET) - İthalat Fiyatları & $-8.18^{*}$ & $-9.02 *$ \\
\hline & D(LNAPECGDP) & $-7.69 *$ & $-10.91 *$ \\
\hline & D(LNAPECREKABET) - İthalat Fiyatları & $-8.78^{*}$ & $-8.86^{*}$ \\
\hline & D(LNEMDEVASİAGDP) & & \\
\hline & D(LNEMDEVASİAREKABET) - İthalat Fiyatları & $-8.58^{*}$ & $-8.84 *$ \\
\hline & D(LNEMDEVGDP) & $-8.58^{*}$ & $-12.06^{*}$ \\
\hline & D(LNEMDEVREKABET) - İthalat Fiyatları & $-9.30 *$ & $-10.43^{*}$ \\
\hline & D(LNMEASTAFRGDP) & $-8.97 *$ & $-12.14^{*}$ \\
\hline & D(LNMEASTAFRREKABET) - İthalat Fiyatları & $-8.78^{*}$ & $-8.86^{*}$ \\
\hline & (LNWORLDGDP) & $-6.93 *$ & $-12.79 *$ \\
\hline & D(LNWORLDREKABET) - İthalat Fiyatlar1 & $-8.33^{*}$ & $-8.97^{*}$ \\
\hline & D(LNADVANCEREKABET) - Deflatör & $-6.08^{*}$ & $-4.99^{*}$ \\
\hline & D(LNAPECREKABET) - Deflatör & $-6.20^{*}$ & $-5.92^{*}$ \\
\hline & D(LNEMDEVASİAREKABET) - Deflatör & $-7.28^{*}$ & $-9.07^{*}$ \\
\hline & D(LNEMDEVREKABET) - Deflatör & $-6.94^{*}$ & $8.17^{*}$ \\
\hline & D(LNMEASTAFRREKABET) - Deflatör & $-7.87^{*}$ & $-7.81^{*}$ \\
\hline & D(LNWORLDREKABET) - Deflatör & $-6.06^{*}$ & $-5.77^{*}$ \\
\hline & D(LNADVGDP) & $-4.43^{* *}$ & $-4.88^{*}$ \\
\hline & D(LNADVANCEREKABET) - İthalat Fiyatları & $-8.11^{*}$ & $-8.48^{*}$ \\
\hline & D(LNAPECGDP) & $-4.00^{*}$ & $-5.69^{*}$ \\
\hline & D(LNAPECREKABET) - İthalat Fiyatları & $-8.73^{*}$ & $-8.82^{*}$ \\
\hline & D(LNEMDEVASİAGDP) & $-4.82^{* *}$ & $-4.20^{* *}$ \\
\hline & D(LNEMDEVASİAREKABET) - İthalat Fiyatları & $-8.60^{*}$ & $-8.92^{*}$ \\
\hline
\end{tabular}


N.ALAKBAROV -M.GÜNDÜZ -M.H.ÖZKAYA

\begin{tabular}{|l|l|l|l|}
\hline \multirow{4}{*}{ Değişkenler } & ADF & PP \\
\cline { 2 - 4 } & D(LNEMDEVGDP) & $-4.00^{* *}$ & $-5.82^{* *}$ \\
\cline { 2 - 4 } & D(LNEMDEVREKABET) - İthalat Fiyatları & $-9.30^{*}$ & $-9.35^{*}$ \\
\cline { 2 - 4 } & D(LNMEASTAFRGDP) & $-5.14^{*}$ & $-5.11^{*}$ \\
\cline { 2 - 4 } & D(LNMEASTAFRREKABET)- İthalat Fiyatları & $-8.73^{*}$ & $-8.82^{*}$ \\
\cline { 2 - 4 } (LNWORLDGDP) & $-4.21^{* *}$ & $-4.60^{* *}$ \\
\cline { 2 - 4 } & D(LNWORLDREKABET) - İthalat Fiyatları & $-8.26^{*}$ & $-9.18^{*}$ \\
\cline { 2 - 4 } & D(LNADVANCEREKABET) - Deflatör & $-6.02^{*}$ & $-4.91^{*}$ \\
\cline { 2 - 4 } & D(LNAPECREKABET) - Deflatör & $-6.13^{*}$ & $-5.89^{*}$ \\
\cline { 2 - 4 } & D(LNEMDEVASİAREKABET) - Deflatör & $-7.24^{*}$ & $-7.38^{*}$ \\
\cline { 2 - 4 } & D(LNEMDEVREKABET) - Deflatör & $-6.60^{*}$ & $-7.49^{*}$ \\
\cline { 2 - 4 } & D(LNMEASTAFRREKABET) - Deflatör & $-7.71^{*}$ & $-7.78^{*}$ \\
\cline { 2 - 4 } & D(LNWORLDREKABET) - Deflatör & $-6.01^{*}$ & $-5.60^{*}$ \\
\hline
\end{tabular}

Not: * ve ** değerleri sırasıyla $\% 1$ ve $\% 5$ anlam seviyelerinde serilerin durağanlıklarını göstermektedir. Optimal gecikme uzunluğu ADF için Schwarz bilgi kriterine göre, PP için Bartlett Kernel Newey-West Bandwidth kriterine göre belirlenmiş̧tir. Değişkenlerin yanlarındaki açıklamalar İthalat Fiyatları ve Deflatör değiş̧kenleri kullanılarak elde edilen Rekabet değişkeni farklılığını belirtmek için verilmiş̧ir.

\section{ARAŞTIRMANIN BULGULARI}

Araştırmada Engle- Granger (1987) iki aşamalı eşbütünleşme testi Dünya geneli, Orta Doğu Afrika Ülkeleri grubu, Gelişmekte Olan Ülkeler grubu, Gelişmekte Olan Asya Ülkeleri grubu, APEC Ülkeleri grubu ve Gelişmiş Ülkeler grubu için yapılmıştır. Eşbütünleşme analiz sonuçları tablolar yardımıyla sunulmuştur. Engle ve Granger'a (1987) göre uzun dönem regresyondan elde edilen hata terimlerinin bir dönem gecikmeli değeri, hata düzeltme terimi olarak kısa dönem regresyona dahil edilerek tahmin edilmektedir. Değişkenler arasında eşbütünleşme ilişkisinin varlı̆̆ 1 uzun dönem modelden elde edilen hata düzeltme teriminin işaretinin negatif, değerinin 1'den küçük ve istatistiksel olarak anlamlı olması durumunda söz konusu olmaktadır.

Tablo-2'de ithalat fiyatları kullanılarak yapılan analiz sonucunda uzun dönem modelden elde edilen hata düzeltme katsayısının işaretinin negatif, değerinin 1'den küçük ve istatistiksel olarak anlamlı olması eşbütünleşme ilişkisinin geçerli olduğu görülmektedir. 
Dokuz Eylül Üniversitesi İktisadi ve İdari Bilimler Fakültesi Dergisi Cilt:32, Sayl:2, Yll:2017, ss. 369-395

Tablo 2. Dünya Geneli

\begin{tabular}{|c|c|c|c|c|c|}
\hline \multicolumn{6}{|c|}{ Uzun dönem } \\
\hline \multicolumn{3}{|c|}{$\begin{array}{l}\text { Ithalat } \\
\text { Fiyatları }\end{array}$} & \multicolumn{3}{|l|}{ Deflatör } \\
\hline Değişkenler & Katsayilar & $\mathrm{t}$ ist. & Değişkenler & Katsayılar & $\mathrm{t}$ ist. \\
\hline $\mathrm{C}$ & $-7.32 *$ & -6.54 & $\mathrm{C}$ & $-8.94 *$ & -10.20 \\
\hline LNWORLDGDP & $2.36^{*}$ & 10.10 & LNWORLDGDP & $2.59 *$ & 14.69 \\
\hline LNWORLDREKABET & $-0.86^{* * *}$ & -1.86 & LNWORLDREKABET & $-0.97 *$ & -4.14 \\
\hline LNKUR & $0.49 * *$ & 2.66 & LNKUR & $0.77 *$ & 4.78 \\
\hline DUMY2008Q4 & $-0.11 *$ & -3.24 & DUMY2008Q4 & $-0.20 *$ & -5.05 \\
\hline DUMY2011Q2 & $-0.16^{* *}$ & -2.71 & & & \\
\hline DUMY2011Q4 & $0.15 * *$ & 2.77 & & & \\
\hline $\mathrm{R}^{2}$ & & 0.97 & $\mathrm{R}^{2}$ & & 0.97 \\
\hline D.W & & 1.90 & D.W. & & 1.83 \\
\hline \multicolumn{6}{|c|}{ Kisa dönem } \\
\hline & \multicolumn{2}{|l|}{$\begin{array}{l}\text { İthalat } \\
\text { Fiyatları }\end{array}$} & \multicolumn{3}{|l|}{ Deflatör } \\
\hline Değişkenler & Katsayılar & $\mathrm{t}$ ist. & Değişkenler & Katsayılar & $\mathrm{t}$ ist. \\
\hline $\mathrm{C}$ & -0.007 & -0.43 & $\mathrm{C}$ & 0.003 & 0.24 \\
\hline D(LNWORLDGDP) & $2.72 * *$ & 4.12 & D(LNWORLDGDP) & $2.43 * *$ & 3.91 \\
\hline $\begin{array}{l}\text { D(LNWORLDREKAB } \\
\text { ET) }\end{array}$ & -0.54 & -1.12 & D(LNWORLDREKABET) & -0.38 & -1.05 \\
\hline $\mathrm{D}(\mathrm{LNKUR})$ & $0.61 * *$ & 2.09 & $\mathrm{D}(\mathrm{LNKUR})$ & 0.42 & 1.14 \\
\hline DUMY2008Q4 & -0.005 & -0.18 & DUMY2008Q4 & -0.005 & -0.26 \\
\hline DUMY2011Q2 & -0.05 & -0.85 & RESID (-1) & $-0.98 *$ & -5.79 \\
\hline DUMY2011Q4 & 0.08 & 1.24 & & & \\
\hline RESID (-1) & $-0.97 *$ & -5.01 & & & \\
\hline $\mathrm{R}^{2}$ & & 0.50 & $\overline{\mathrm{R}^{2}}$ & & 0.51 \\
\hline D.W & & 1.94 & D.W. & & 2.07 \\
\hline
\end{tabular}

Not: Anlamlılık düzeyleri (\%1, \%5, \%10) olarak sırasıyla (*,**,***) ile gösterilmiştir. Diğer katsayılar istatistiksel olarak anlamsızdır.

Burada uzun dönem kur katsayısı ve gelir katsayısının, kısa dönem katsayısına göre daha küçük olması dikkat çekmektedir. Bu sonuca bağlı olarak Türkiye’nin ihracatı açısından hem kısa dönemde hem de uzun dönemde kur etkisinin geçerli olduğu ve bu etkinin uzun dönemde daha düşük olduğu söylenebilir. Gelir değişkeni 


\section{N.ALAKBAROV -M.GÜNDÜZ -M.H.ÖZKAYA}

ise hem kısa dönemde hem de uzun dönemde istatistiksel olarak anlamlıdır ve katsayının işareti de beklenildiği gibi pozitiftir. Bu sonuca göre dünya genelinde oluşabilecek bir krizin Türkiye ihracatı üzerinde olumsuz bir etki meydana getireceğ $\mathrm{i}$ söylenebilir. Analiz sonucunda uzun dönem rekabet katsayının işaretinin beklentiler dâhilinde negatif olduğu görülmektedir. Fakat katsayının değerinin 1'den küçük olması Türkiye ihracatının fiyat esnekliğinin büyük olmadığı; yani Türkiye'de yerleşik firmaların dünya firmaları ile fiyat rekabetine girmelerinin kendilerine avantaj sağlamayacağı biçiminde yorumlanabilir. Tabloda görüldüğü gibi uzun dönem modelde kullanılan kukla değişkenler istatistiksel olarak anlamlıdır. Türkiye'nin dünya geneline yaptığ 1 ihracat, 2008 yılı 4'cü çeyreği ve 2011 y1lı 2'ci çeyreğinden sonra azaldığı, buna karşın 2011 yılı 4'cü çeyreğinden sonra ise arttığ görülmektedir. Bu sonuç 2008 küresel krizinin Türkiye'nin ihracatını olumsuz yönde etkilediğini göstermektedir.

Deflatör kullanılarak yapılan modelde de eşbütünleşme ilişkisinin olduğu görülmektedir. Çünkü kısa dönem analizinde uzun dönem modelden elde edilen hata düzeltme katsayısının işareti negatif, katsayının değeri 1'den küçük ve istatistiksel olarak anlamlıdır. $\mathrm{Bu}$ analiz sonucunda kur ve rekabet katsayılarının kısa dönemde anlamsız olduğu, sadece gelir katsayısının kısa dönemde anlamlı olduğu görülmektedir. Bununla birlikte tüm katsayıların uzun dönemde hem istatistiksel olarak anlamlı olduğu hem de işaretlerinin beklentilere uygun olduğu görülmektedir. Gelir katsayısının hem kısa hem de uzun dönemde istatistiksel olarak anlamlı olması dünya genelinde oluşabilecek bir krizin Türkiye ihracatını olumsuz yönde etkileyebileceğini ortaya koymaktadır. İthalat fiyatları modelinde olduğu gibi, bu modelde de uzun dönemde 2008 yılı 4'cü çeyreği ve sonrası ile öncesinin farklılığını ifade eden kukla değişkenin istatistiksel olarak anlamlı olduğu görülmektedir. İlgili değişkenin işaretinin eksi olması, 2008 yılı 4'cü çeyreği ve sonrasının öncesi ile kıyaslandığında, Türkiye'nin ihracatında azalma olduğunu göstermektedir. $\mathrm{Bu}$ bulguya bağlı olarak 2008 küresel krizinin Türkiye ihracatı üzerinde olumsuz etkilediği sonucuna ulaşılabilir. 
Dokuz Eylül Üniversitesi İktisadi ve İdari Bilimler Fakültesi Dergisi Cilt:32, Sayl:2, Yll:2017, ss. 369-395

Tablo 3. Orta Doğu Afrika Ülkeleri Grubu

\begin{tabular}{|c|c|c|c|c|c|}
\hline \multicolumn{6}{|c|}{ Uzun dönem } \\
\hline \multicolumn{3}{|c|}{$\begin{array}{l}\text { İthalat } \\
\text { Fiyatları }\end{array}$} & \multicolumn{3}{|l|}{ Deflatör } \\
\hline Değişkenler & Katsayılar & $\mathrm{t}$ ist. & Değişkenler & Katsayılar & $\mathrm{t}$ ist. \\
\hline $\mathrm{C}$ & 3.64 & 1.57 & $\mathrm{C}$ & -2.59 & -1.43 \\
\hline LNMEASTAFRGDP & 0.14 & 0.31 & LNMEASTAFRGDP & $1.82 *$ & 3.24 \\
\hline $\begin{array}{l}\text { LNMEASTAFR- } \\
\text { REKABET }\end{array}$ & $-1.14 *$ & -3.66 & LNMEASTAFRREKABET & $-0.60 * *$ & -2.31 \\
\hline LNKUR & $1.43^{*}$ & 5.22 & LNKUR & $1.12 *$ & 4.17 \\
\hline DUMY2006Q3 & $0.11 * *$ & 2.38 & DUMY2008Q4 & $-0.23 *$ & -2.86 \\
\hline DUMY2008Q4 & $-0.32 *$ & -3.89 & & & \\
\hline $\mathrm{R}^{2}$ & & 0.92 & $\mathrm{R}^{2}$ & & 0.90 \\
\hline D.W & & 1.24 & D.W. & & 1.11 \\
\hline \multicolumn{6}{|c|}{ Kısa dönem } \\
\hline & \multicolumn{2}{|l|}{$\begin{array}{l}\text { İthalat } \\
\text { Fiyatları }\end{array}$} & \multicolumn{3}{|l|}{ Deflatör } \\
\hline Değişkenler & Katsayılar & t ist. & Değişkenler & Katsayılar & $\mathrm{t}$ ist. \\
\hline $\mathrm{C}$ & 0.02 & 0.76 & $\mathrm{C}$ & 0.01 & 0.60 \\
\hline $\begin{array}{l}\text { D(LNMEASTAFR- } \\
\text { GDP) }\end{array}$ & 0.004 & 0.38 & D(LNMEASTAFRGDP) & $1.03 * *$ & 2.16 \\
\hline $\begin{array}{l}\text { D(LNMEASTAFR- } \\
\text { REKABET) }\end{array}$ & $-0.94 *$ & -2.95 & D(LNMEASTAFRREKABET) & -0.15 & -0.49 \\
\hline D(LNKUR) & $1.27 *$ & 3.07 & D(LNKUR) & 0.67 & 1.53 \\
\hline DUMY2006Q3 & -0.01 & -0.31 & DUMY2008Q4 & -0.01 & -0.43 \\
\hline DUMY2008Q4 & -0.02 & -0.48 & RESID (-1) & $-0.49 *$ & -2.94 \\
\hline RESID (-1) & $-0.55^{*}$ & -2.95 & & & \\
\hline $\mathrm{R}^{2}$ & \multirow{2}{*}{\multicolumn{2}{|c|}{$\begin{array}{l}0.33 \\
2.00\end{array}$}} & $\mathrm{R}^{2}$ & & 0.28 \\
\hline D.W & & & D.W. & & 2.06 \\
\hline
\end{tabular}

Not: Anlamlılık düzeyleri (\%1, \%5, \%10) olarak sırasıyla (*,**,***) ile gösterilmiştir. Diğer katsayılar istatistiksel olarak anlamsızdır.

Tablo-3'te ithalat fiyatları kullanılarak yapılan analiz sonucunda uzun dönem ilişkisinin olduğu görülmektedir. İhracat malları fiyat esnekliği katsayısı olan rekabet katsayısı 1'den büyüktür. Başka bir ifade ile Türkiye bu ülke grubuna ihracat yaptığında, ilgili ülke grubuna ihracat yapan diğer ülke firmaları ile önemli boyutta 


\section{N.ALAKBAROV -M.GÜNDÜZ -M.H.ÖZKAYA}

fiyat rekabeti içindedir. Modelde aynı zamanda gelir katsayısının istatistiksel olarak anlamsız olduğu görülmektedir. Bu durumun ilgili ülke grubunun gelir düzeyinin istikrarsız olmasından kaynaklandığı düşünülebilir. Bu sonuç ilgili ülke grubuna yapılacak ihracatta Türkiye açısından özellikle çapraz kur etkisinin ve fiyat etkisinin daha önemli olacağını göstermektedir. İlgili tabloda görüldüğü gibi uzun dönem modelde kullanılan kukla değişkenler istatistiksel olarak anlamlıdır. Türkiye'nin Orta Doğu Afrika Ülkeleri grubuna yaptığı ihracatın özellikle 2008 y1lı 4'cü çeyreğinden sonra önemli ölçüde azaldığı görülmektedir. Bu bulgu bağlamında 2008 küresel krizinin Türkiye'nin ilgili ülke grubuna yaptığı ihracatı üzerinde olumsuz etkiye yol açtığı ifade edilebilir.

Deflatör kullanılarak oluşturulan Orta Doğu Afrika Ülkeleri grubu modelinde değişkenler arasında uzun dönem ilişkisinin olduğu görülmektedir. İlgili ülke grubu kısa dönem analizinde uzun dönem modelden elde edilen hata düzeltme terimi negatif, katsayının değeri 1'den küçük ve istatistiksel olarak anlamlıdır. Uzun dönemde tüm katsayılar anlamlı ve katsayıların işaretleri beklentiler dâhilindedir. Fakat hata düzeltme katsayısının 0.49 gibi daha düşük bir değer alması (diğer tüm ülke grupları modelleri ile kıyaslandığında en düşük değerdir) kısa ve uzun dönem arasındaki dengesizliklerin giderilmesinin daha uzun bir zaman alacağını işaret etmektedir. Kısa dönemde ise sadece gelir katsayısı istatistiksel olarak anlamlıdır. İthalat fiyatları modelinde olduğu gibi, bu modelde de uzun dönemde 2008 yılı 4'cü çeyreği ve sonrası ile öncesinin farklılığını ifade eden kukla değişkenin istatistiksel olarak anlamlı olduğu ve işaretinin eksi görülmektedir. Bu analiz sonucuna dayalı olarak 2008 yılı 4'cü çeyreği ve sonrasının öncesi ile karşılaştırıldığında Türkiye'nin ilgili ülke grubuna yönelik ihracatında azalma olduğu söylenebilir.

Tablo 4. Gelişmekte Olan Ülkeler Grubu

\begin{tabular}{|l|l|l|l|l|l|}
\hline \multicolumn{7}{|c|}{ Uzun dönem } \\
\hline \multicolumn{3}{|c|}{$\begin{array}{l}\text { İthalat } \\
\text { Fiyatları }\end{array}$} & Deflatör \\
\hline Değişkenler & Katsayılar & t ist. & Değişkenler & Katsayılar & t ist. \\
\hline C & $-1.82^{* *}$ & -1.99 & C & $-2.25^{*}$ & -3.81 \\
\hline LNEMDEVGDP & $1.20^{*}$ & 6.41 & LNEMDEVGDP & $1.12^{*}$ & 7.58 \\
\hline
\end{tabular}


Dokuz Eylül Üniversitesi İktisadi ve İdari Bilimler Fakültesi Dergisi Cilt:32, Sayl:2, Yll:2017, ss. 369-395

\begin{tabular}{|c|c|c|c|c|c|}
\hline $\begin{array}{l}\text { LNEMDEV- } \\
\text { REKABET }\end{array}$ & -0.22 & -0.93 & LNEMDEVREKABET & $-1.04 *$ & -4.01 \\
\hline LNKUR & $0.47 * *$ & 2.26 & LNKUR & $0.68 *$ & 4.32 \\
\hline DUMY2009Q3 & $-0.11^{* *}$ & -2.18 & DUMY2008Q4 & $-0.31 *$ & -6.51 \\
\hline $\mathrm{R}^{2}$ & & 0.94 & $\mathrm{R}^{2}$ & & 0.97 \\
\hline D.W & & 1.26 & D.W. & & 1.75 \\
\hline \multicolumn{6}{|c|}{ Kisa dönem } \\
\hline \multicolumn{3}{|c|}{$\begin{array}{l}\text { İthalat } \\
\text { Fiyatları }\end{array}$} & \multicolumn{3}{|l|}{ Deflatör } \\
\hline Değişkenler & Katsayilar & t ist. & Değişkenler & Katsayılar & $\mathrm{t}$ ist. \\
\hline $\mathrm{C}$ & 0.02 & 1.18 & $\mathrm{C}$ & 0.001 & 0.07 \\
\hline D(LNEMDEVGDP) & -0.02 & -0.22 & D(LNEMDEVGDP) & $1.54 *$ & 3.35 \\
\hline $\begin{array}{l}\text { D(LNEMDEV- } \\
\text { REKABET) }\end{array}$ & -0.30 & -1.17 & D(LNEMDEVREKABET) & -0.31 & -0.86 \\
\hline D(LNKUR) & $0.68 * *$ & 2.14 & D(LNKUR) & 0.36 & 0.93 \\
\hline DUMY2009Q3 & -0.006 & -0.22 & DUMY2008Q4 & -0.01 & -0.43 \\
\hline RESID (-1) & $-0.57 *$ & -3.44 & RESID (-1) & $-0.96^{*}$ & -5.14 \\
\hline $\mathrm{R}^{2}$ & \multirow{2}{*}{\multicolumn{2}{|c|}{$\begin{array}{l}0.29 \\
2.01\end{array}$}} & $\mathrm{R}^{2}$ & & 0.47 \\
\hline D.W & & & D.W. & & 2.05 \\
\hline
\end{tabular}

Not: Anlamlılık düzeyleri (\%1, \%5, \%10) olarak sırasıyla (*,**,***) ile gösterilmiştir. Diğer katsayılar istatistiksel olarak anlamsızdır.

İthalat fiyatları kullanılarak yapılan analiz sonucunda uzun dönem ilişkisinin olduğu Tablo-4'te görülmektedir. Modelde uzun dönem fiyat esnekliğini gösteren rekabet katsayısı istatistiksel olarak anlamsızdır. Gelir esnekliği ise uzun dönemde 1 'den büyüktür. Bu durum ilgili ülke grubuna ihracat yapan diğer ülke firmaları ile rekabet içinde olunmadığını, buna karşın Gelişmekte Olan Ülkeler grubuna yapılan ihracatta söz konusu ülke grubunun gelir seviyesindeki değişmelerin Türkiye'nin ihracatında etkili olacağını göstermektedir. Uzun dönem modelde kullanılan 2009 yılı 3'cü çeyreği ve sonrası ile öncesi arasındaki farklılığı gösteren kukla değişken istatistiksel olarak anlamlıdır ve işareti de negatiftir. Bu sonuç Türkiye'nin Gelişmekte Olan Ülkeler grubuna yaptığı ihracatın özellikle 2009 yılı 3'cü çeyreğinden sonra önemli ölçüde azaldığını sunmaktadır.

Deflatör kullanılarak oluşturulan Gelişmekte Olan Ülkeler grubu modelinde değişkenler arasında uzun dönem ilişkisinin olduğu görülmektedir. Bu model diğer 


\section{N.ALAKBAROV -M.GÜNDÜZ -M.H.ÖZKAYA}

modellerle karşılaştırıldığında fiyat esnekliğinin (rekabet katsayısının) büyük olduğu dikkat çekmektedir. Bu durum Türkiye'de yerleşik firmalar tarafından bu ülkelere yapılan ihracatta analiz edilen ülke grubu firmalarıyla fiyat rekabeti içinde olduğunu göstermektedir. Aynı zamanda uzun dönem gelir esnekliğinin kısa dönem gelir esnekliğinden küçük olması, uzun dönemde Türkiye'nin bu bölgeye yaptığı ihracatın kısa döneme göre etkisinin daha az olduğu sonucunu vermektedir. Söz konusu tabloda uzun dönem modelinde 2008 y1lı 4'cü çeyreği ve sonrası ile öncesinin farklılığını ifade eden kukla değişkenin istatistiksel olarak anlamlı ve işaretinin negatif olduğu görülmektedir. Bu sonuç 2008 yılı 4'cü çeyreği ve sonrasının öncesine kıyasla Türkiye'nin ilgili ülke grubuna yönelik ihracatında azalma olduğunu göstermektedir.

Tablo 5. Gelişmekte Olan Asya Ülkeleri Grubu

\begin{tabular}{|c|c|c|c|c|c|}
\hline \multicolumn{6}{|c|}{ Uzun dönem } \\
\hline \multicolumn{3}{|l|}{ İthalat Fiyatlar1 } & \multicolumn{3}{|l|}{ Deflatör } \\
\hline Değişkenler & Katsayılar & $t$ ist. & Değişkenler & Katsayılar & $t$ ist. \\
\hline $\mathrm{C}$ & $-1.13 * * *$ & -1.84 & $\mathrm{C}$ & $-1.75^{*}$ & -3.37 \\
\hline $\begin{array}{l}\text { LNEMDEVASIA- } \\
\text { GDP }\end{array}$ & $0.10^{*}$ & 8.34 & $\begin{array}{l}\text { LNEMDEVASIAGD } \\
\mathrm{P}\end{array}$ & $1.06^{*}$ & 8.66 \\
\hline $\begin{array}{l}\text { LNEMDEVASIA- } \\
\text { REKABET }\end{array}$ & $-0.61 *$ & -2.98 & $\begin{array}{l}\text { LNEMDEVASIA- } \\
\text { REKABET }\end{array}$ & $-0.83^{* *}$ & -2.39 \\
\hline LNKUR & $0.59 *$ & 3.48 & LNKUR & $0.60 * *$ & 2.70 \\
\hline DUMY2009Q3 & $-0.15^{*}$ & -3.00 & DUMY2008Q4 & $-0.31 *$ & -6.18 \\
\hline DUMY2011Q2 & $-0.17^{* *}$ & -2.05 & & & \\
\hline \multicolumn{2}{|l|}{$\overline{\mathrm{R}^{2}}$} & 0.94 & \multicolumn{2}{|l|}{$\mathrm{R}^{2}$} & 0.96 \\
\hline \multicolumn{2}{|l|}{ D.W } & 1.61 & \multicolumn{2}{|l|}{ D.W. } & 1.66 \\
\hline \multicolumn{6}{|c|}{ Kisa dönem } \\
\hline \multicolumn{3}{|l|}{ İthalat Fiyatları } & \multicolumn{3}{|l|}{ Deflatör } \\
\hline Değişkenler & Katsayılar & $\mathrm{t}$ ist. & Değişkenler & Katsayılar & $\mathrm{t}$ ist. \\
\hline $\mathrm{C}$ & -0.01 & -0.51 & $\mathrm{C}$ & -0.004 & -0.29 \\
\hline $\begin{array}{l}\text { D(LNEMDEVASIA- } \\
\text { REKABET) }\end{array}$ & -0.002 & -0.02 & $\begin{array}{l}\text { D(LNEMDEVASIA- } \\
\text { GDP) }\end{array}$ & $1.51 *$ & 4.21 \\
\hline $\begin{array}{l}\text { D(LNEMDEVASIA- } \\
\text { GDP) }\end{array}$ & $1.45^{*}$ & 4.48 & $\begin{array}{l}\text { D(LNEMDEVASIA- } \\
\text { REKABET) }\end{array}$ & 0.08 & 0.20 \\
\hline$\overline{\mathrm{D} \text { (LNKUR) }}$ & 0.44 & 1.69 & $\overline{\mathrm{D} \text { (LNKUR) }}$ & 0.27 & 0.72 \\
\hline
\end{tabular}


Dokuz Eylül Üniversitesi İktisadi ve İdari Bilimler Fakültesi Dergisi

Cilt:32, Sayl:2, Yll:2017, ss. 369-395

\begin{tabular}{|l|l|l|l|l|l|}
\hline DUMY2009Q3 & -0.01 & -0.29 & DUMY2008Q4 & -0.005 & -0.26 \\
\hline DUMY2011Q2 & 0.01 & 0.33 & RESID (-1) & $-0.87^{*}$ & -4.99 \\
\hline RESID (-1) & $-0.75^{*}$ & -5.18 & & & 0.49 \\
\hline$R^{2}$ & 0.50 & $R^{2}$ & 2.02 \\
\hline D.W & 1.93 & D.W. \\
\hline
\end{tabular}

Not: Anlamlılık düzeyleri $(\% 1, \% 5, \% 10)$ olarak sırasıyla $(*, * *, * * *)$ ile gösterilmiştir. Diğer katsayılar istatistiksel olarak anlamsızdır.

Tablo-5'te görüldüğü üzere ithalat fiyatları kullanılarak yapılan analize göre Gelişmekte olan Asya Ülkeleri Grubu modelinde eşbütünleşme ilişkisinin geçerlidir. Burada özellikle kısa dönem gelir esnekliği katsayısının 1.45, uzun dönem gelir esnekliği katsayısının ise 0.10 gibi düşük bir değer alması dikkat çekmektedir. $\mathrm{Bu}$ durum ilgili ülke grubunun gelir seviyesinde meydana gelecek olan değişmelerin uzun dönemde Türkiye'nin ihracatını önemli oranda etkilemeyeceğini göstermektedir. Diğer taraftan fiyat esnekliği katsayısını veren rekabet katsayısının uzun dönemde hem istatistiksel olarak anlamlı olduğu hem de katsayının işaretinin beklendiği gibi negatif olduğu görülmektedir. Bu durum Türkiye'nin ilgili ülke grubuna yapacağı ihracatta ilgili ülke grubunun gelir seviyesindeki değişmelerden az etkilendiği ve Türk firmalarının ilgili ülke grubuna ihracat yapan diğer ülke firmaları ile rekabet edebilir konumda olduğu şeklinde değerlendirilebilir.

Tabloda uzun dönem modelde kullanılan 2009 yılı 3'cü çeyreği ve sonrası ve 2011 yılı 2'ci çeyreği ve sonrası ile öncesi arasındaki farklılığı gösteren kukla değişkenler istatistiksel olarak anlamlıdır ve değişkenlerin işaretinin de negatiftir. Bu sonuç Türkiye'nin Gelişmekte Olan Ülkeler grubuna yaptığı ihracatının 2009 yılından itibaren azaldığını göstermektedir.

Deflatör kullanılarak yapılan analizin bulguları, Gelişmekte Olan Asya Ülkeleri modeli için eşbütünleşme ilişkisinin geçerli olduğunu göstermektedir. Çünkü kısa dönem analizinde uzun dönem modelden elde ettiğimiz hata düzeltme teriminin işareti hem negatif, hem katsayı 1'in altında, hem de istatistiksel olarak anlamlıdır. Modelde fiyat esnekliğinin (rekabet katsayısının) 1'den küçük olduğu, aynı zamanda uzun dönem gelir esnekliğinin de kısa dönem gelir esnekliğinden küçük olduğu görülmektedir. Bu sonuç, bu bölgedeki gelir artışının Türkiye'nin uzun dönemde bu 


\section{N.ALAKBAROV -M.GÜNDÜZ -M.H.ÖZKAYA}

bölgeye yapacağı ihracatın kısa dönemle kıyaslandığında olumlu etkisinin daha az olacağını göstermektedir.

Tabloda uzun dönem modelde 2008 yıl1 4'cü çeyreği ve sonrası ile öncesinin farklılığını ifade eden kukla değişkenin istatistiksel olarak anlamlı olduğu görülmektedir. İlgili değişkenin işaretinin eksi olması ise 2008 yılı 4'cü çeyreği ve sonrasında Türkiye'nin ilgili ülke grubuna yönelik ihracatının azaldığını göstermektedir.

Tablo 6. APEC Ülkeleri Grubu

\begin{tabular}{|c|c|c|c|c|c|}
\hline & & un döne & (2001q1-2013q4) & & \\
\hline İthalat Fiyatları & & & Deflatör & & \\
\hline Değişkenler & Katsayılar & t ist. & Değişkenler & Katsayılar & $\mathrm{t}$ ist. \\
\hline $\mathrm{C}$ & $-5.57 *$ & -4.52 & $\mathrm{C}$ & $-8.04 *$ & -9.45 \\
\hline LNAPECGDP & $2.01 *$ & 7.98 & LNAPECGDP & $2.40^{*}$ & 14.67 \\
\hline LNKUR & $0.44 * *$ & 2.59 & LNAPECREKABET & $-0.77^{*}$ & -2.89 \\
\hline LNAPECREKABET & $-0.31 * *$ & -1.89 & LNKUR & $0.67 *$ & 3.70 \\
\hline DUMY2008Q4 & $-0.18^{*}$ & -3.42 & DUMY2008Q4 & $-0.18^{*}$ & -4.56 \\
\hline DUMY2011Q2 & $-0.13 * *$ & -2.45 & & & \\
\hline DUMY2011Q4 & $0.20^{*}$ & 2.78 & & & \\
\hline $\mathrm{R}^{2}$ & & 0.96 & $\mathrm{R}^{2}$ & & 0.97 \\
\hline D.W & & 1.70 & D.W. & & 1.98 \\
\hline & & sa dönes & (2001q1-2013q4) & & \\
\hline İthalat Fiyatları & & & Deflatör & & \\
\hline Değişkenler & Katsayilar & $\mathrm{t}$ ist.. & Değişkenler & Katsay1lar & $\mathrm{t}$ ist. \\
\hline $\mathrm{C}$ & -0.001 & -0.03 & $\mathrm{C}$ & 0.001 & 0.10 \\
\hline D(LNAPECGDP) & $2.20 *$ & 3.63 & D(LNAPECGDP) & $2.33 *$ & 4.22 \\
\hline D(LNKUR) & $0.73 * *$ & 2.54 & D(LNAPECREKABET) & -0.30 & -0.82 \\
\hline D(LNAPECREKABET) & $-0.31 * * *$ & -1.81 & D(LNKUR) & 0.51 & 1.40 \\
\hline DUMY2008Q4 & -0.02 & -0.59 & DUMY2008Q4 & -0.003 & -0.17 \\
\hline DUMY2011Q2 & -0.05 & -0.85 & RESID (-1) & $-1.10^{*}$ & -6.65 \\
\hline DUMY2011Q4 & 0.09 & 1.54 & & & \\
\hline RESID (-1) & $-0.95^{*}$ & -5.24 & & & \\
\hline $\mathrm{R}^{2}$ & & 0.52 & $\mathrm{R}^{2}$ & & 0.56 \\
\hline D.W & & 1.91 & D.W. & & 1.94 \\
\hline
\end{tabular}


Dokuz Eylül Üniversitesi İktisadi ve İdari Bilimler Fakültesi Dergisi Cilt:32, Sayl:2, Yll:2017, ss. 369-395

\begin{tabular}{|c|c|c|c|c|c|}
\hline \multicolumn{6}{|c|}{ APEC Ülkeleri (2000q1-2013q4) } \\
\hline \multicolumn{3}{|l|}{$\begin{array}{l}\text { Deflatör(Uzun } \\
\text { Dönem) }\end{array}$} & \multicolumn{3}{|l|}{ Deflatör (Kısa Dönem) } \\
\hline Değişkenler & Katsayılar & t ist. & Değişkenler & Katsayilar & $\mathrm{t}$ ist. \\
\hline $\mathrm{C}$ & $-8.98^{*}$ & -11.13 & $\mathrm{C}$ & 0.003 & 0.24 \\
\hline LNAPECGDP2 & $2.54 *$ & 16.01 & D(LNAPECGDP2) & $2.16^{*}$ & 4.10 \\
\hline Değişkenler & Katsay1lar & $\mathrm{t}$ ist. & Değişkenler & Katsayılar & $\mathrm{t}$ ist. \\
\hline LNAPECREKABET & $-1.14^{*}$ & -4.84 & D(LNAPECREKABET) & -0.62 & -1.62 \\
\hline LNKUR & $0.90^{*}$ & 5.58 & D(LNKUR) & $0.74 * *$ & 2.11 \\
\hline \multirow[t]{2}{*}{ DUMY2008Q4 } & $-0.22 *$ & -5.87 & DUMY2008Q4 & -0.005 & -0.25 \\
\hline & & & RESID (-1) & $-0.96^{*}$ & -5.87 \\
\hline \multicolumn{2}{|l|}{$\mathrm{R}^{2}$} & 0.97 & \multicolumn{2}{|l|}{$\mathrm{R}^{2}$} & 0.51 \\
\hline \multicolumn{2}{|l|}{ D.W. } & 1.74 & \multicolumn{2}{|l|}{ D.W. } & 2.06 \\
\hline
\end{tabular}

Not: Anlamlılık düzeyleri (\%1, \%5, \%10) olarak sırasıyla (******) ile gösterilmiştir. Diğer katsayılar istatistiksel olarak anlamsızdır.

Tablo-6'da ithalat fiyatları kullanılarak yapılan analize göre APEC ülkeleri grubu modelinde eşbütünleşme ilişkisinin geçerli olduğu görülmektedir. Burada gelir esnekliğinin yukarıdaki diğer modellerden çok daha yüksek olması dikkat çekici bir unsurdur. Yukarıdaki diğer ülke gruplarından farklı olarak APEC ülkeleri grubunun gelişmişlik seviyesi daha yüksek olan ülkeleri de içermesinin bu sonucun elde edilmesinde etkili olduğu düşünülmektedir. Başka bir deyişle, Türkiye ihracat pazarları açısından gelişmiş ülkelerin önemli potansiyele sahip olduğu ifade edilebilir. Aynı zamanda bu ülkelerde olası ekonomik krizin Türkiye'nin ihracatı üzerinde olumsuz sonuçlar doğuracağı beklenebilir. Bir diğer sonuç da fiyat katsayısını veren rekabet değişkenin \%5' seviyesinde değil, \%10 seviyesinde anlamlı olduğudur. $\mathrm{Bu}$ durum Türkiye'de yerleşik firmaların bu ülke grubuna yaptıkları ihracatta ilgili ülke grubuna ihracat yapan diğer ülke firmaları ile rekabet içinde olmadıkları sonucunu vermektedir. Dolayısıyla Türkiye'nin dış ticaret politikasının oluşturulmasında bu sonucun göz önünde bulundurulması önem arz etmektedir. Uzun dönem modelde kullanılan 2008 yılı 4'cü çeyreği ve sonrası ile öncesi arasındaki farklılığı gösteren kukla değişken istatistiksel olarak anlamlı 


\section{N.ALAKBAROV -M.GÜNDÜZ -M.H.ÖZKAYA}

olduğu ve değişkenin işaretinin de negatif olduğu görülmektedir. $\mathrm{Bu}$ sonuç Türkiye'nin APEC ülkeleri grubuna yaptığı ihracatının 2008 yılı 4'cü çeyreğinden sonra azaldığııı göstermektedir.

Deflatör kullanılarak yapılan analiz APEC ülkeleri grubu modelinde eşbütünleşme ilişkisinin 2001q1-2013q4 (2001 y1l 1. çeyreği ve 2013 yıl1 4. çeyreği) dönemi için geçerli olmadığı görülmektedir. Çünkü uzun dönemden elde edilen hata düzeltme katsayısı 1'den büyüktür. Bu sonuç Türkiye'de yerleşik firmaların ilgili ülke grubunda yerleşik firmalarla rekabet edemediğini göstermektedir. Fakat analiz dönemine 2000 yılı dahil edildiğinde, eşbütünleşme ilişkisinin geçerli olduğu ve modelin istatistiksel olarak anlamlı sonuç verdiği görülmektedir. Bu ülke grubunda özellikle ABD, Rusya ve Çin gibi ülkelerin Türkiye'nin dış ticaret potansiyeli açısından önemli olması nedeniyle, analiz döneminin bu ülke grubu için 2000 yılının ilave edilmesi yoluyla gerek modelde kayda değer bulguya ulaşılması, gerekse yeni araştırmalara ilham kaynağı olması açısından önem taşıdığı düşünülmektedir. Söz konusu dönemde Türkiye'de iki önemli ekonomik kriz yaşanmıştır (2000 Kasım krizi ve 2001 Şubat krizi). Bu krizler sonucunda Türk parası önemli ölçüde değer kaybetmiştir. Buna bağlı olarak Türkiye'nin bu ülke grubuna yapacağı ihracatı açısından önemli rekabet avantajı sağlanmıştır. İki dönem dikkate alındığında rekabet ve kur katsayılarının 2000q1-2013q4 modelinde oldukça yüksek olduğu görülmektedir. 2000q1-2013q4 modelinde rekabet endeksi olan fiyat esnekliğinin 1'den büyük olduğu görülmektedir. Bu da Türkiye açısından kur endeksinin oluşturabileceği bir rekabet avantajının bu ülke grubu açısından önemli olduğunu göstermektedir. 
Dokuz Eylül Üniversitesi İktisadi ve İdari Bilimler Fakültesi Dergisi Cilt:32, Sayl:2, Yll:2017, ss. 369-395

Tablo 7: Gelişmiş Ülkeler Grubu

\begin{tabular}{|c|c|c|c|c|c|}
\hline & & Uzun & jnem & & \\
\hline İthalat Fiyatları & & & Deflatör & & \\
\hline Değişkenler & Katsayılar & $\mathrm{t}$ ist. & Değişkenler & Katsayılar & $\mathrm{t}$ ist. \\
\hline $\mathrm{C}$ & $-9.22 *$ & -4.61 & $\mathrm{C}$ & $-24.45^{*}$ & -8.33 \\
\hline LNADVGDP & $2.78 *$ & 6.54 & LNADVGDP & $5.92 *$ & 9.93 \\
\hline LNADVANCEREKABET & $-1.44 * *$ & -2.12 & LNADVREKABET & $-1.14 *$ & -3.17 \\
\hline LNKUR & $0.98^{*}$ & 3.44 & LNKUR & $0.66^{*}$ & 2.83 \\
\hline DUMY2007Q1 & $0.17^{*}$ & 3.65 & DUMY2007Q3 & $1.07 *$ & 7.27 \\
\hline & & & DUMY2007Q4 & $-0.89 *$ & -6.32 \\
\hline $\mathrm{R}^{2}$ & & 0.88 & $\mathrm{R}^{2}$ & & 0.94 \\
\hline D.W & & 1.63 & D.W. & & 1.80 \\
\hline & & Kisa & nem & & \\
\hline İthalat Fiyatları & & & Deflatör & & \\
\hline Değişkenler & Katsayılar & $\mathrm{t}$ ist. & Değişkenler & Katsayılar & $\mathrm{t}$ ist. \\
\hline $\mathrm{C}$ & 0.02 & 1.03 & $\mathrm{C}$ & $0.03 * * *$ & 1.66 \\
\hline D(LNADVGDP) & $0.94 *$ & 2.88 & D(LNADVGDP) & 0.23 & 0.53 \\
\hline D(LNADVANCEREKABET & -0.21 & $\begin{array}{l}- \\
0.42\end{array}$ & D(LNADVREKABET) & 0.24 & 0.56 \\
\hline $\mathrm{D}$ (LNKUR) & $0.71 * *$ & 2.27 & $\mathrm{D}$ (LNKUR) & 0.17 & 0.38 \\
\hline DUMY2007Q1 & -0.01 & $\overline{-}-35$ & DUMY2007Q3 & -0.10 & $\overline{0}-82$ \\
\hline RESID (-1) & $-0.55^{*}$ & $-\overline{4.48}$ & DUMY2007Q4 & 0.09 & 0.70 \\
\hline & & & RESID (-1) & $-0.67 *$ & $-\overline{4.70}$ \\
\hline$\overline{\mathrm{R}^{2}}$ & & 0.35 & $\mathrm{R}^{2}$ & & 0.39 \\
\hline D.W & & 2.18 & D.W. & & 2.08 \\
\hline
\end{tabular}

Not: Anlamlılık düzeyleri (\%1, \%5, \%10) olarak sırasıyla $(*, * *, * * *)$ ile gösterilmiştir. Diğer katsayılar istatistiksel olarak anlamsızdir.

Tablo-7'de ithalat fiyatları dikkate alınarak yapılan analiz sonucunda, Gelişmiş Ülkeler grubu modelinde eşbütünleşme ilişkisinin olduğu görülmektedir. Gelir esnekliğinin diğer tüm ülke gruplarından daha büyük bir değer alarak 3'e yakın olması dikkat çekmektedir. Diğer bir ifade ile,ilgili ülke grubu gelirinde meydana gelen \%1'lik bir artışın Türkiye'nin bu ülkelere olan ihracatını yaklaşık \%3 oranında 


\section{N.ALAKBAROV -M.GÜNDÜZ -M.H.ÖZKAYA}

artırması beklenmektedir. Bunun yanı sıra gelir esnekliği değişkeninin kısa dönemde istatistiksel olarak anlamlı olduğu görülmektedir. Bununla birlikte fiyat esnekliği katsayısının uzun dönemde 1'in çok üzerinde olması önem taşımaktadır. Bu sonuç Türkiye'nin ilgili ülke grubuna ihracat yaptığında bu ülke grubuna ihracat yapan diğer ülke firmaları ile de rekabet ettiğini ortaya koymaktadır. Kur değişkeninin de 1'e yakın çok yüksek bir değer alması çapraz kurdaki değişmelerin Türkiye açısından önemli olduğunu göstermektedir. Başka bir deyişle, Euro para biriminin ABD Doları karşısında değer kazanması Türkiye'nin ihracatını olumlu etkileyecektir. Tabloda uzun dönem modelde kullanılan 2007 y1lı 1'ci çeyreği ve sonrası ile öncesi arasındaki farklılığı gösteren kukla değişken istatistiksel olarak anlamlı ve değişkenin işaretinin pozitif olduğu görülmektedir. $\mathrm{Bu}$ durum Türkiye'nin Gelişmiş Ülkeler grubuna yaptığı ihracatın 2007 yılı 1'ci çeyreğinden sonra arttı̆̆ını ortaya koymaktadır.

Deflatör kullanılarak yapılan analiz Gelişmiş Ülkeler modeli için eşbütünleşme ilişkisinin geçerli olduğunu göstermektedir. Kısa dönemde hiçbir değişkenin istatistiksel olarak anlamlı olmamasına rağmen, uzun dönemde tüm değişkenlerin anlamlı olması dikkat çekmektedir. Aynı zamanda hem gelir esnekliğinin hem de fiyat esnekliğinin diğer ülke gruplarıyla karşılaştırıldığında oldukça yüksek olması, Türkiye'nin ihracat pazarı açısından gelişmiş ülkeler grubunun önem arz ettiğini göstermektedir. $\mathrm{Bu}$ analiz sonucuna bağl1 olarak gelişmiş ülkelerin ve özellikle $\mathrm{AB}$ ülkelerinin Türkiye'nin dış ticaretinde önemli paya sahip olma potansiyelini sürdürdüğü ifade edilebilir. Uzun dönem modeli için 2007 y1lı 3'cü çeyreği ve sonrası ve 4'cü çeyreği ve sonrası ile öncesinin farklılı̆̆ını ifade eden kukla değişkenlerin istatistiksel olarak anlamlı olduğu görülmektedir. 2007 y1lı 3'cü çeyreği ve sonrası ile öncesinin farklılığını gösteren değişkenin pozitif olması ve değerinin 1,07 gibi yüksek olması, belirtilen dönemden sonra Türkiye ihracatının ilgili ülke grubuna önemli oranda arttı̆̆ını göstermektedir. Öte yandan 2007 yılı 4'cü çeyreği ve sonrası ile öncesinin farklılı̆̆ını ifade eden kukla değişkenin istatistiksel olarak anlamlı ve işaretinin negatif olması belirtilen dönemden sonra Türkiye'nin Gelişmiş Ülkeler grubuna yönelik ihracatının azaldığını göstermektedir. Bu bulgu 
2007 yılının ikinci yarısından itibaren etkilerini göstermeye başlayan küresel finansal krizin Türkiye ihracatını olumsuz yönde etkilemesiyle açıklanabilir. Bununla birlikte diğer modellerle karşılaştırıldığında bu olumsuz etkinin nispeten yüksek olması, gelişmiş ülkeler ekonomilerinin küresel krizden daha çok etkilenmesine bağlı olarak yorumlanabilir.

\section{SONUÇ}

Bu çalışma Türkiye'nin 2001-2013 dönemi için çeyreklik veriler kullanılarak yapılan ihracat talep fonksiyonunun farklı ülke gruplarına yönelik analizini içermektedir. Ülkelerin refah düzeylerinin artmasında dış ticaretin önemli bir unsur olduğu açıktır. Bu bağlamda ihracatın fiyat ve gelir esneklikleri ülkelerin ihracat talebinin değerlendirilmesinde göz önünde bulundurulması gereken önemli değişkenlerdendir.

Türkiye 1980 sonrası ihracata dayalı sanayileşme stratejisini benimsemiş ve böylelikle uluslararası rekabeti ön plana çıaran büyüme modelini uygulamaya koymuştur. Türkiye bu dönemde aynı zamanda dış ticaret pazarlarını da çeşitlendirmeye yönelik adımlar atmıştır. Bu bağlamda özellikle 2000'li y1llardan itibaren pazar çeşitlendirmesine yönelik girişimlerin ivme kazandığı görülmektedir.

Çalışmadan elde edilen bulgular bütün ülke gruplarında ihracatın gelir esnekliğinin fiyat esnekliğinden daha yüksek olduğunu göstermektedir. Özellikle Orta Doğu Afrika ve Gelişmekte Olan Asya Ülkeleri Grubu ülkeleri için gelir esnekliğinin diğer tüm ülke gruplarından daha küçük olduğu görülmektedir. Orta Doğu Afrika ülkelerine yönelik gelir esnekliğinin uzun dönemde kısa dönem ile karşılaştırıldığında oldukça küçük bir değer alması Türkiye'nin Orta Doğu Afrika ülkelerine olan ihracatı açısından olumsuz olarak değerlendirilebilir. Tüm modellerde kullanılan kukla değişkenlerden de görüldüğü gibi Türkiye'nin ihracat talebini etkileyen en önemli faktörlerden biri de 2008 küresel ekonomik krizidir. 2008 küresel krizinin Türkiye'nin ihracat talebi üzerinde hissedilir ölçüde olumsuz yönde etkilediği ortaya çıkmaktadır. 


\section{N.ALAKBAROV -M.GÜNDÜZ -M.H.ÖZKAYA}

Orta Doğu Afrika ve Gelişmekte Olan Asya Ülkeleri Grubu ülkelerine ilişkin bulunan sonuçlar, aslında Türkiye'de dış ticarette eksen kayması anlamında yapılan tartışmaları desteklememektedir. Bu sonuç (Alakbarov ve Gökalp, (2016)) tarafından yapılan ihracatın ithalatı karşılama oranı ile ilgili değerlendirmeyle de örtüşmektedir. Alakbarov ve Gökalp (2016) Türkiye'nin farklı ülke grupları ile dış ticaretini incelemiş ve en önemli pazarın eskiden olduğu gibi yine $\mathrm{AB}$ olduğunu, uzun dönemde Kuzey Amerika'nın da Türkiye için önemli pazar oluşturacağını belirtmişlerdir. Bu bağlamda değerlendirildiğinde Gelişmiş Ülkeler Grubu ve APEC Ülkeleri Grubunun ihracat taleplerinin gelir ve fiyat esnekliklerinin diğer ülke gruplarından daha büyük olduğu görülmektedir. Bu ülke grupları ağırlıklı olarak $\mathrm{AB}$ ve Kuzey Amerika ülkelerini kapsadığından $A B$ ile olan ekonomik ilişkilerin güçlendirilmesi ve pazar çeşitlendirilmesi kapsamında Kuzey Amerika ülkelerine ağılık verilmesi Türkiye'nin ihracatına ve büyüme kapasitesinin artırılmasına önemli katk1 sağlayacaktır.

\section{KAYNAKÇA}

AKTAŞ, C., YILMAZ, V. (2008), “Gümrük Birliği Sonrası Türkiye'nin İhracat Fonksiyonunun Tahmini”. İstanbul Ticaret Üniversitesi Sosyal Bilimler Dergisi, 7 (13) Bahar 2008, 89-104.

ALAKBAROV, N., GÖKALP, M. F. (2016), “Küresel Ekonomik Gelişmeler Ve Transatlantik Serbest Ticaret Anlaşması Çerçevesinde Türkiye'nin İhracat Pazarları Sorunu", Scientific Cooperation for the Future in the Social Sciences Usak International Conference-2016, 22nd-23rd September 2016, Uşak, Türkiye, 11-27.

AYDIN, F., SAYGILI, M. (2007), "Empirical Analysis of Structural Change in Turkish Exports”, TCMB Çalışma Tebliği, No: 07/08.

BOZOK, İ., DOĞAN, Ş. B., YÜNCÜLER, Ç. (2015), Estimating Income and Price Elasticity of Turkish Exports with Heterogeneous Panel Time - Series Methods, CBRT Working Paper, No: 15/26.

CULHA, O. Y., KALAFATCILAR, M. K., (2014), “Türkiye'de İhracatın Gelir ve Fiyat Esnekliklerine Bir Bakıș: Bölgesel Farklılıkların Önemi”, TCMB Ekonomi Notlarl, Sayı: 2014-05/ 09 Nisan 2014. 
DICKEY, D. A., FULLER W. A., (1981), "Likelihood Ratio Statistics for Autoregressive Time Series with a Unit Root”, Econometrica, (49), 1057-72.

DICKEY, D. A., FULLER W. A., (1979), "Distribution of the Estimators for Autoregressive Time Series with a Unit Root". Journal of the American Statistical Association, 74, 427-431.

DOĞANLAR, M., H. BAL, ÖZMEN, M., (2004), "Uluslararası Ticaret ve Türkiye'nin İhracat Fonksiyonu”, Manas Üniversitesi S.B.E Dergisi, Say1:7, 83-109.

ENDERS, W., (1995), Applied Econometric Time Series, New York: Wiley.

ENGLE, R.F., GRANGER, C.W. J., (1987), "Cointegration and ErrorCorrection: Representation, Estimation and Testing”, Econometrica, S.66, 251-276.

ERDOĞAN COŞAR E, (2002), "Price and Income Elasticities of Turkish Export Demand: A Panel Data Application", Central Bank Review 2.

FULLERTON, T. M, JR., SAWYER, JR. W. C., SPRINKLE, R. L. (1999), "Latin American Trade Elasticities. Journal of Economics \& Finance", 23, Summer 1999, 143-156.

GRANGER, C.W.J., NEWBOLD, P. (1974), "Spurious regressions in Economics", Journal of Econometrics, 4, 111-120.

KETENCI, N. (2014), "Trade Elasticities, Commodity Prices, and the Global Financial Crisis: Evidence from BRIICS Countries and Turkey", Global Journal of Emerging Market Economies, 6(3), 233-256.

KHAN, M.S. (1974), "Import and Export Demand in Developing Countries”, IMF Staff Papers, 21, 678-693.

KUMAR, S. (2011), "Estimating export demand equations in selected Asian countries", Journal of Chinese Economic and Foreign Trade Studies, 4 (1), 5-16. 


\section{N.ALAKBAROV -M.GÜNDÜZ -M.H.ÖZKAYA}

PERRON, P. (1989), "The Great Crash, the Oil Price Shock and the Unit Root Hypothesis", Econometrica, 57, 1361-1401.

PHILLIPS, P.C.B., PERRON, P. (1988), "Testing for unit roots in time series regression”, Biometrika, 75(2), 335-346.

RAO, B. B., SINGH, R. (2007), "Estimating Export Equations". Applied Economics Letters, 14, 799-802.

SAATCIOĞLU, C., KARACA, O. " Dolar/Euro Paritesinin Türkiye'nin İhracatına Etkisi: Ekonometrik bir Analiz”, Niğde Üniversitesi İ.I.B.F Dergisi, 2010, 3 (2), 106-118.

SENHADJI, A., MONTENEGRO, C. (1999), "Time Series Analysis of Export Demand Equations: A Cross-Country Analysis", IMF Staff Papers, 46 (3).

ŞIMŞEK, M., KADILAR, C. (2005), "Türkiye'nin İhracat Talebi Fonksiyonunun Sınır Testi Yöntemi İle Eşbütünleşme Analizi”, Doğuş Üniversitesi Dergisi, 6 (1), 144-152.

TOGAN, S. BERUMENT, H. (2007), "The Turkish Current Account, Real Exchange Rate and Sustainability: A Methodological Framework", The Journal of International Trade and Diplomacy, 1 (1), Spring, 155-192. 
Ek

\begin{tabular}{|c|c|}
\hline Değişkenler & Değişkenler \\
\hline $\begin{array}{l}\text { LNADVGDP - } \\
\text { Gelişmiş Ülkeler GSYH }\end{array}$ & $\begin{array}{l}\text { LNMEASTAFRREKABET- } \\
\text { İthalat Fiyatları }\end{array}$ \\
\hline $\begin{array}{l}\mathrm{D}(\mathrm{LNADVGDP})- \\
\text { Gelişmiş Ülkeler GSYH birinci farkı }\end{array}$ & $\begin{array}{l}\text { D(LNMEASTAFRREKABET) - } \\
\text { İthalat Fiyatları }\end{array}$ \\
\hline $\begin{array}{l}\text { LNADVANCEREKABET - } \\
\text { İthalat Fiyatları ile Gelişmiş Ülkeler Rekabet } \\
\text { Endeksi }\end{array}$ & LNWORLDGDP \\
\hline $\begin{array}{l}\text { D(LNADVANCEREKABET) - } \\
\text { İthalat Fiyatları ile Gelişmiş Ülkeler Rekabet } \\
\text { Endeksi birinci farkı }\end{array}$ & (LNWORLDGDP) \\
\hline Değişkenler & Değişkenler \\
\hline LNAPECGDP - APEC GSYH & $\begin{array}{l}\text { LNWORLDREKABET- } \\
\text { İthalat Fiyatları }\end{array}$ \\
\hline $\begin{array}{l}\text { D(LNAPECGDP) - } \\
\text { APEC GSYH birinci fark1 }\end{array}$ & $\begin{array}{l}\text { D(LNWORLDREKABET) - } \\
\text { İthalat Fiyatları }\end{array}$ \\
\hline LNAPECREKABET - İthalat Fiyatları & LNADVANCEREKABET - Deflatör \\
\hline $\begin{array}{l}\text { D(LNAPECREKABET) - } \\
\text { İthalat Fiyatları }\end{array}$ & D(LNADVANCEREKABET) - Deflatör \\
\hline LNEMDEVASİAGDP & LNAPECREKABET - Deflatör \\
\hline D(LNEMDEVASİAGDP) & D(LNAPECREKABET) - Deflatör \\
\hline $\begin{array}{l}\text { LNEMDEVASİAREKABET- } \\
\text { İthalat Fiyatları }\end{array}$ & LNEMDEVASİAREKABET- Deflatör \\
\hline $\begin{array}{l}\text { D(LNEMDEVASİAREKABET) - } \\
\text { İthalat Fiyatları }\end{array}$ & $\begin{array}{l}\text { D(LNEMDEVASİAREKABET) } \\
\text { Deflatör }\end{array}$ \\
\hline LNEMDEVGDP & LNEMDEVREKABET- Deflatör \\
\hline D(LNEMDEVGDP) & D(LNEMDEVREKABET) - Deflatör \\
\hline LNEMDEVREKABET- İthalat Fiyatları & LNMEASTAFRREKABET- Deflatör \\
\hline D(LNEMDEVREKABET) - İthalat Fiyatları & D(LNMEASTAFRREKABET) - Deflatör \\
\hline LNMEASTAFRGDP & LNWORLDREKABET- Deflatör \\
\hline D(LNMEASTAFRGDP) & D(LNWORLDREKABET) - Deflatör \\
\hline
\end{tabular}

